\title{
Millet and corn oil in sorghum-based diets for broilers
}

\author{
Milheto e óleo de milho em dietas a base de sorgo para frangos de corte
}

\author{
João Paulo Rodrigues Bueno ${ }^{I^{*}}$ Mara Regina Bueno de Mattos Nascimento ${ }^{\text {II }}$ \\ Carolina Magalhães Caires Carvalho' ${ }^{I}$ Evandro de Abreu Fernandes ${ }^{I I}$ \\ Marina Cruvinel Assunção Silva ${ }^{I}$ Julyana Machado da Silva Martins ${ }^{\text {III }}$ Fernanda Heloisa Litz
}

ABSTRACT

This study evaluated the effects of millet and corn oil additions to sorghum-based diets on the performance, carcass yields and prime cuts (i.e., wings, breasts, thighs and drumsticks) and the relative weights of edible offal (i.e., gizzard, heart, and liver) of broiler chickens. A total of 684 Hubbard Flex chickens, including 342 broilers of each sex, were housed. The design was completely randomized, and the following diets were supplied: A) sorghum and soybean meal + soybean oil (control); B) sorghum and soybean meal + corn oil; and C) sorghum and soybean meal + millet and soybean oil. Six replicates with 38 birds each (19 males and 19 females) were evaluated regarding each experimental diet At 14, 21, 35 and 42 days of age, the feed intake, weight gain, feed conversion and viability of the chickens were evaluated. At 42 days, the live weight, carcass yield, prime cuts and relative weight of the edible offal were measured. The dietary inclusion of either millet or corn oil did not affect any of the parameters. In conclusion, additions of millet and corn oil to sorghum-based diets of broilers do not compromise poultry performance.

Key words: animal nutrition, carcass yield, Pennisetum glaucum performance, poultry.

RESUMO

Objetivou-se avaliar os efeitos da inclusão de milheto e óleo de milho em dietas a base de sorgo sobre o desempenho, rendimento de carcaça e de cortes nobres (asas, peito, coxa e sobrecoxa) e peso relativo das vísceras comestiveis (moela, coração e figado) de frangos de corte. Foram alojadas 684 aves, sendo 342 de cada sexo, da linhagem Hubbard Flex. O delineamento foi inteiramente casualisado, composto pelas dietas:
A) sorgo+farelo de sojalóleo de soja (controle), B) sorgo+farelo de soja/óleo de milho e C) sorgo+farelo de soja/milheto+óleo de soja. Cada dieta experimental foi avaliada em seis repetições de 38 aves cada (19 machos e 19 fêmeas). Aos 14, 21, 35 e 42 dias de idade das aves, avaliou-se o consumo de ração, ganho de peso, conversão alimentar e viabilidade. Aos 42 dias, foi obtido o peso vivo, rendimento de carcaça e de cortes nobres, além do peso relativo das vísceras comestiveis. A inclusão de milheto ou óleo de milho nas dietas não alterou nenhum dos parâmetros avaliados. Concluiu-se que, em dietas a base de sorgo para frangos de corte, $o$ milheto e o óleo de milho podem ser adicionados sem comprometer a produtividade das aves.

Palavras-chave: aves, desempenho, nutrição animal, Pennisetum glaucum, rendimento de carcaça.

\section{INTRODUCTION}

The commercial broiler has high nutritional efficiency; furthermore, it shows rapid development, providing a healthy source of protein at a low cost to the consumer. However, creating new approaches to reach higher levels of productivity remains challenging; for example, changes in price and the availability of the key grains used in their feed (i.e., corn and soybean) affect productivity (FURLAN, 2006; UBABEF, 2013).

Thus, attempts are made to replace a reliance on grains such as corn because the market is variable, and the use of grains at certain times of the year raises

\footnotetext{
IPrograma de Pós-graduação em Ciências Veterinárias, Faculdade de Medicina Veterinária (FAMEV), Universidade Federal de Uberlândia (UFU), Av. Pará, 1720, Umuarama, 38400-750, Uberlândia, MG, Brasil. E-mail: jprbueno@hotmail.com. *Corresponding author. IFAMEV, UFU, Uberlândia, MG, Brasil.

IIIPrograma de Pós-graduação em Zootecnia, Escola de Veterinária e Zootecnia (EVZ), Universidade Federal de Goiás (UFG), Goiânia, GO, Brasil. 
the cost of feed. Grains such as sorghum and millet are nutritionally similar to corn and might be alternatives as feed (LEITE et al., 2011; ROSTAGNO et al., 2011).

The nutritional value of sorghum is high in formulating diets for broilers and is therefore a possible total replacement for corn. In addition, millet has a higher crude protein content than corn but similar levels of the amino acid lysine; however, the metabolizable energy values of millet are lower than those for corn (ROSTAGNO et al., 2011).

The oils and fats added to the diet of broilers greatly benefit their productivity; however, their use raises the final cost of feed (NASCIF et al., 2004). Nevertheless, corn oil (a by-product of the corn processing industry) has higher energy values than soybean oil (NASCIF et al., 2004; BAIÃO \& LARA, 2005), and it is often extracted in large volumes by certain industries, resulting in a greater supply than demand.

Therefore, this study evaluated the effects of millet and corn oil additions to sorghum-based diets on the performance (i.e., feed intake, weight gain, feed conversion, live weight and viability), carcass yields, prime cuts (i.e., wings, breasts, thighs and drumsticks) and the relative weights of edible offal (i.e., gizzard, heart, and liver) of broiler chickens.

\section{MATERIAL AND METHODS}

This experiment was conducted from November to December 2013 in the experimentation shed on the Glory farm of the Universidade Federal de Uberlândia, Minas Gerais, Brazil. The shed had a brick and metal frame and was built with tiles covering a concrete floor; moreover, it had screened walls, double-side curtains (internal and external) and was lined with plastic fabric.

The control system for temperature (T) and relative humidity $(\mathrm{RH})$ inside the shed included fans, foggers and infrared bells (only used during the first week of the bird's life). The means and standard deviations of the weekly $\mathrm{T}$ and $\mathrm{RH}$ values were as follows: Week $1\left(\mathrm{~T}=29.0 \pm 6.6^{\circ} \mathrm{C} ; \mathrm{RH}=59.9 \pm 22.3 \%\right)$; Week $2\left(\mathrm{~T}=24.1 \pm 7.2^{\circ} \mathrm{C} ; \quad \mathrm{RH}=72.1 \pm 22.1 \%\right)$; Week $3 \quad\left(\mathrm{~T}=23.5 \pm 6.5^{\circ} \mathrm{C} ; \quad \mathrm{RH}=79.2 \pm 26.18 \%\right)$; Week $4\left(\mathrm{~T}=24.9 \pm 6.0^{\circ} \mathrm{C}\right.$; $\left.\mathrm{RH}=77.6 \pm 21.0 \%\right)$; Week $5\left(\mathrm{~T}=24.7 \pm 6.7^{\circ} \mathrm{C} ; \mathrm{RH}=79.9 \pm 22.0 \%\right)$; and Week 6 $\left(\mathrm{T}=24.7 \pm 5.7^{\circ} \mathrm{C} ; \mathrm{RH}=82.6 \pm 21.6 \%\right)$.

A total of 684 broiler chicks, all within one day of age, were housed. Male and female Hubbard
Flex chickens were purchased from breeders at a commercial hatchery. Birds came from the same batch and were incubated under the same conditions. These birds were distributed using a completely randomized design, and three diets were evaluated: A) sorghum and soybean meal + soybean oil (control); B) sorghum and soybean meal + corn oil; and C) sorghum and soybean meal + millet and soybean oil (Table 1). Each treatment was composed of 228 birds distributed in six replicates (i.e., boxes) of 38 birds (19 males and 19 females) for a density of 12.5 birds $\mathrm{m}^{-2}$. Each box was equipped with a tubular feeder and an automatic child drinker for the first week of the birds' lives; this device was replaced with a pendulum drinker over the following weeks. The floor of the box was covered with wood shavings.

The raw materials were chemically analyzed to verify the composition of ingredients. All diets were formulated to meet the nutritional requirements of the birds as reported by ROSTAGNO et al. (2011). The food program was composed of four successive diets that were determined by the age of the chicken: pre-starter (1-7 days), early (8-21 days), fattening (22-33 days) and slaughter (34-42 days).

The birds were provided with diet and drinking water ad libitum (3-5mg $\mathrm{mL}^{-1}$ of chlorine) during the experimental period. From days 1 to 7,8 to 21 and 22 to 42 , the lighting program was two, four and two hours of dark, respectively.

To provide thermal comfort, the $\mathrm{T}$ and $\mathrm{RH}$ of the shed were maintained within the recommended range for this lineage. The $\mathrm{T}$ and $\mathrm{RH}$ were monitored daily every three hours with dataloggers (HOMIS 404A) installed at three locations in the shed to within $30 \mathrm{~cm}$ of the poultry house litter.

At 14, 21, 35 and 42 days of age, all of the birds from each box were weighed on a Ramuza DP300 model digital scale (precision=50grams) to obtain weekly weight gain and final weight. Feed intake was calculated as the difference between the amount of feed and the remainder divided by the number of birds in each box. Feed conversion was calculated based on the relationship between feed intake and weight gain, after accounting for the weight of dead birds (recorded daily). Viability was calculated as the difference between the numbers of live and dead birds at the beginning of each phase.

At 42 days, 6 male broilers from each treatment were selected with individual weights close to the average weight for birds in the plot 
Table 1 - Ingredients, percent composition and calculated nutritional values of the feeds with soybean oil (A), corn oil (B) and millet (C) for broilers within the pre-starter (1-7 days), early (8-21 days), fattening (22-33 days) and slaughter (34-42 days) phases.

\begin{tabular}{|c|c|c|c|c|}
\hline \multirow{2}{*}{ Ingredients (\%) } & Pre-starter & Early & Fattening & \multirow[t]{2}{*}{ Slaughte } \\
\hline & \multicolumn{3}{|c|}{ 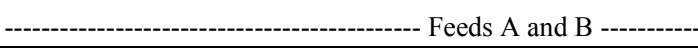 } & \\
\hline Sorghum $8.6 \%$ & 55.72 & 57.61 & 60.21 & 61.97 \\
\hline Soybean meal $46.5 \%$ & 36.47 & 33.84 & 30.53 & 29.03 \\
\hline Soybean oil (A) or Corn oil (B) & 3.67 & 4.86 & 5.96 & 6.02 \\
\hline Dicalcium phosphate $18 \%$ & 1.90 & 1.52 & 1.32 & 1.05 \\
\hline Limestone & 0.78 & 0.84 & 0.78 & 0.71 \\
\hline Salt & 0.46 & 0.46 & 0.45 & 0.45 \\
\hline DL-Methionine (98\%) & 0.37 & 0.32 & 0.22 & 0.28 \\
\hline L-Lysine HCL (79\%) & 0.31 & 0.27 & 0.26 & 0.23 \\
\hline L-Threonine (98.5\%) & 0.12 & 0.08 & 0.07 & 0.06 \\
\hline Vitamin-mineral supplement & $0.20^{1}$ & $0.20^{1}$ & $0.20^{2}$ & $0.20^{3}$ \\
\hline Apparent metabolizable energy (Mcal kg $\left.{ }^{-1}\right)$ & $\begin{array}{l}\text { Calculated } \mathrm{n} \\
\quad 2.955\end{array}$ & $\begin{array}{r}\text { npositio } \\
3.054\end{array}$ & 3.152 & 3.201 \\
\hline Crude protein $(\%)$ & 22.35 & 21.19 & 19.80 & 19.20 \\
\hline Calcium $(\%)$ & 0.91 & 0.83 & 0.75 & 0.65 \\
\hline Available phosphorus (\%) & 0.46 & 0.39 & 0.35 & 0.30 \\
\hline Potassium $(\%)$ & 0.84 & 0.80 & 0.75 & 0.73 \\
\hline Sodium $(\%)$ & 0.22 & 0.22 & 0.21 & 0.21 \\
\hline Digestible lysine (\%) & 1.30 & 1.20 & 1.11 & 1.04 \\
\hline Digestible Methionine + Cysteine $(\%)$ & 0.94 & 0.86 & 0.81 & 0.76 \\
\hline Ingredients (\%) & & ------- & --------' & \\
\hline Sorghum $8.6 \%$ & 29.12 & 31.00 & 31.71 & 36.05 \\
\hline Millet grain & 28.00 & 28.00 & 30.00 & 30.00 \\
\hline Soybean meal $46.5 \%$ & 35.22 & 32.59 & 29.19 & 25.93 \\
\hline Soybean oil & 3.55 & 4.75 & 5.84 & 5.07 \\
\hline Dicalcium phosphate $18 \%$ & 1.91 & 1.54 & 1.35 & 1.08 \\
\hline Limestone & 0.79 & 0.84 & 0.78 & 0.72 \\
\hline Salt & 0.46 & 0.46 & 0.45 & 0.45 \\
\hline DL-Methionine (98\%) & 0.35 & 0.30 & 0.19 & 0.23 \\
\hline L-Lysine HCL (79\%) & 0.30 & 0.26 & 0.25 & 0.24 \\
\hline L-Threonine (98.5\%) & 0.10 & 0.06 & 0.04 & 0.03 \\
\hline Vitamin-mineral supplement & $0.20^{1}$ & $0.20^{1}$ & $0.20^{2}$ & $0.20^{3}$ \\
\hline Apparent metabolizable energy $\left(\mathrm{Mcal} \mathrm{kg}^{-1}\right)$ & $\begin{array}{l}\text { Calculated } \mathrm{n} \\
\quad 2.955\end{array}$ & $\begin{array}{r}\text { npositio } \\
3.054\end{array}$ & 3.152 & 3.201 \\
\hline Crude protein $(\%)$ & 22.82 & 21.67 & 20.30 & 20.04 \\
\hline Calcium $(\%)$ & 0.91 & 0.83 & 0.75 & 0.65 \\
\hline Available phosphorus (\%) & 0.46 & 0.39 & 0.35 & 0.30 \\
\hline Potassium $(\%)$ & 0.84 & 0.79 & 0.74 & 0.70 \\
\hline Sodium $(\%)$ & 0.22 & 0.22 & 0.21 & 0.21 \\
\hline Digestible lysine (\%) & 1.30 & 1.20 & 1.11 & 1.04 \\
\hline Digestible Methionine + Cysteine $(\%)$ & 0.94 & 0.86 & 0.81 & 0.76 \\
\hline
\end{tabular}

${ }^{1}(\mathrm{~kg} /$ product): Vitamin A 1,600,000IU, Vitamin B12 2,000mcg, Vitamin D3 400,000IU, Vitamin E 3,000mg, K 400mg, Zn $12.6 \mathrm{~g}, \mathrm{Cu}$ $1,260 \mathrm{mg}$, Se $80 \mathrm{mg}$, Fe 10.5g, I 252mg, Mn 12.6g, Folic acid 140mg, Pantothenic acid 1600mg, Bacitracin Zn 11g, Biotin 12mg, Choline $70 \mathrm{~g}$, Monensin 22 , and Niacin 6,000 g. ${ }^{2}(\mathrm{~kg} /$ product): Vitamin A 1,280,000IU, Vitamin B12 1,600mcg, Vitamin D3 350,000IU, Vitamin E 2,400mg, K 300mg, Zn 12g, Cu 1,200mg, Se 60mg, Fe 10g, I 240mg, Mn 12g, Folic acid 100mg, Pantothenic acid 1,600mg, Halquinol $6,000 \mathrm{mg}$, Biotin $6 \mathrm{mg}$, Choline 50g, Salinomycin 13,2g, and Niacin 4,800mg. ${ }^{3}(\mathrm{~kg} /$ product): Vitamin A 1,300,260IU, Vitamin B12 1,667mcg, Vitamin D3 400,000IU, Vitamin E 2,167.1mg, K 333.4mg, Zn 20 g, Cu 2,000mg, Se 60.68mg, Fe 16.6g, I 400mg, Mn 20g, Folic acid $100 \mathrm{mg}$, Pantothenic acid 1,333mg, Virginiamycin 3,666mg, Biotin $6.67 \mathrm{mg}$, Choline 50g, and Niacin 4,000mg.

( $\pm 5 \%$ variation). These birds were slaughtered in accordance with the rules and official procedures (BRASIL, 1998) to determine the carcass yield (i.e., without feathers or viscera), the prime cuts (i.e., the thighs, drumsticks, wings and breasts with bone), and the relative weights of the heart, gizzard and liver. 
The data obtained in this study were tested for normality using the Kolmogorov-Smirnov test and homogeneity of variance using Levene's test. These data checks were followed by analysis of variance using Sisvar ${ }^{\circledR}$ : a computer statistical analysis system. The means were compared using the Scott-Knott test at $5 \%$ probability.

\section{RESULTS AND DISCUSSION}

The feed intake, weight gain, feed conversion, viability and weight at slaughter of broilers fed diets formulated with millet and corn oil were similar to those that received the control diet at $14,21,35$ and 42 days of age $(\mathrm{P}>0.05$; Table 2$)$. These results are likely because the nutritional levels of the diets were similar and close to the diet recommended by ROSTAGNO et al. (2011).

The use of soybean oil in diets positively affects poultry performance (ANDREOTTI et al., 2004; COSTA et al., 2008), and replacement with other oils such as linseed oil (ALMEIDA et al., 2009) does not interfere with the productive performance of broilers; the current study replaced soybean oil with corn oil and made similar observations.

The metabolizable energy of corn oil $\left(8,773 \mathrm{kcal} \mathrm{kg}^{-1}\right)$ approaches to soybean oil $(8,790 \mathrm{kcal}$ $\mathrm{kg}^{-1}$; ROSTAGNO et al., 2011); in fact, NASCIF et al. (2004) found that it is higher (corn oil: $8,666 \mathrm{kcal} \mathrm{kg}^{-1} \mathrm{vs}$. soybean oil: $8,336 \mathrm{kcal} \mathrm{kg}^{-1}$ ). BAIÃO \& LARA (2005) reported additional values of $8,886 \mathrm{kcal} \mathrm{kg}^{-1}$ (corn oil) and $8,790 \mathrm{kcal} \mathrm{kg}^{-1}$ (soybean oil). Furthermore, HARMS et al. (2004) observed that corn oil increased the amount of energy ingested among laying hens, with subsequent improvement in performance. Thus, the results of previous research indicate that soybean oil can be replaced using corn oil, without compromising the performance of broiler chickens.

MAIORKA et al. (2008) concluded that the inclusion of vegetable oil in the isocaloric diets of broilers increased feed intake from 6 to 10,10 to 15 and 15 to 20 days of age. Moreover, birds preferred diets with higher levels of oil; however, the inclusion of vegetable oil did not affect the final performance of the birds.

Table 2 - Feed intake, weight gain, feed conversion, live weight and viability of broilers at 14, 21, 35 and 42 days of age fed with differen1 diets in Uberlândia, Minas Gerais, 2013.

\begin{tabular}{|c|c|c|c|c|c|}
\hline Diets & Feed intake (kg) & Weight gain $(\mathrm{kg})$ & Feed conversion & Live weight (kg) & Viability (\%) \\
\hline$A^{1}$ & 0.61 & 0.49 & 1.37 & - & 99.56 \\
\hline $\mathrm{B}^{2}$ & 0.62 & 0.49 & 1.40 & - & 97.80 \\
\hline $\mathrm{C}^{3}$ & 0.63 & 0.49 & 1.39 & - & 98.68 \\
\hline $\mathrm{CV} \% * *$ & 4.76 & 4.79 & 7.27 & - & 2.08 \\
\hline P-value * & 0.74 & 0.88 & 0.90 & - & 0.36 \\
\hline A & 1.29 & 0.94 & 1.44 & - & 99.56 \\
\hline B & 1.32 & 0.96 & 1.44 & - & 96.93 \\
\hline $\mathrm{C}$ & 1.30 & 0.95 & 1.44 & - & 98.68 \\
\hline $\mathrm{CV} \%$ & 2.84 & 3.78 & 3.68 & - & 2.86 \\
\hline P-value & 0.52 & 0.81 & 0.99 & - & 0.28 \\
\hline $\mathrm{A}$ & 3.41 & 2.05 & 1.70 & - & 99.12 \\
\hline B & 3.49 & 2.10 & 1.69 & - & 95.61 \\
\hline $\mathrm{C}$ & 3.42 & 2.07 & 1.68 & - & 98.24 \\
\hline CV\% & 3.12 & 4.79 & 3.24 & - & 3.94 \\
\hline P-value & 0.38 & 0.61 & 0.78 & - & 0.28 \\
\hline A & 4.49 & 2.56 & 1.87 & 2.68 & 98.24 \\
\hline B & 4.72 & 2.59 & 1.88 & 2.70 & 95.61 \\
\hline $\mathrm{C}$ & 4.66 & 2.57 & 1.84 & 2.70 & 96.05 \\
\hline $\mathrm{CV} \%$ & 3.78 & 4.56 & 5.31 & 2.02 & 4.98 \\
\hline P-value & 0.09 & 0.87 & 0.80 & 0.75 & 0.60 \\
\hline
\end{tabular}

**Coefficient of variation; *Significant at $\mathrm{P}<0.05$. ${ }^{1} \mathrm{~A}(\mathrm{Control})=$ Sorghum and soybean meal + soybean oil; ${ }^{2} \mathrm{~B}=\mathrm{Sorghum}$ and soybean meal + corn oil; and ${ }^{3} \mathrm{C}=$ Sorghum and soybean meal + millet and soybean oil. 
When considering the amount of added millet diets, with the inclusion of up to $30 \%$ millet used in this study, our results were consistent with those of DAVIS et al. (2003), who tested feed from corn (not sorghum) and soybean meal, concluding that the addition of up to $50 \%$ millet did not change the performance of broilers.

According to GOMES et al. (2008), the inclusion of millet in broiler diets during the initial phase (up to 21 days of age) should be at a maximum of $20 \%$ so that the amount of oil does not exceed $4.8 \%$ and affect the mixture and feed storage. In the current study, however, the level of soybean oil used did not exceed the recommended $4.8 \%$, even with levels of up to $28 \%$ millet included during the initial phase. Thus, the performance of the birds fed with a millet diet did not change compared with those fed a diet without millet.

HIDALGO et al. (2004) did not find a difference in the performance of broilers from 1 to 15 days of age or throughout the complete cycle of production (1-42 days) with diets that contained $10 \%$ millet. In addition, MURAKAMI et al. (2009), who added higher levels of millet to the diet $(20 \%, 40 \%$, $60 \%, 80 \%$ and $100 \%$ ), found lower production costs without losses of performance.

BAURHOO et al. (2011) verified that diets formulated with 100\% millet decreased feed intake but resulted in better feed conversion ratios, demonstrating that the birds showed improved grain use even with lower intake. Moreover, LEITE et al. (2012) observed that diets with more than 50\% millet improved performance among broilers at 42 days of age compared with those fed with sorghum. Although the energy value of millet $\left(3,165 \mathrm{kcal} \mathrm{kg}^{-1}\right)$ is less than that of sorghum $\left(3,189 \mathrm{kcal} \mathrm{kg}^{-1}\right)$ according to ROSTAGNO et al. (2011), the latter has more crude protein $(12.71 \%)$ and fat $(3.95 \%)$ than sorghum $(8.97 \%$ crude protein and $2.96 \%$ fat).

The broilers at 42 days of age fed with diets formulated with both corn oil and millet + soybean oil had carcass yields (without feathers or viscera) and relative prime cut weights similar to those that received the control diet $\mathrm{P}>0.05$; (Table 3 ). These results are likely because the birds fed with different diets had similar body weights, and carcass yields and prime cuts are directly proportional to body weight. Applying diets containing up to $50 \%$ millet, DAVIS et al. (2003) also observed that the carcass yields of broilers at 42 days of age were not affected.

Moreover, ALMEIDA et al. (2009) did not find a change in carcass yields after replacing soybean oil with linseed oil. In another study, the addition of up to $7.5 \%$ poultry slaughterhouse oil in
Table 3 - Carcass yield and prime cuts (breasts, thighs/drumsticks and wings) of broilers at 42 days of age fed with different diets in Uberlandia, Minas Gerais, 2013.

\begin{tabular}{lcccc}
\hline Diets & $\begin{array}{c}\text { Carcass } \\
\text { Yield (\%) }\end{array}$ & $\begin{array}{c}\text { Breasts } \\
(\%)\end{array}$ & $\begin{array}{c}\text { Thighs/ } \\
\text { drumsticks (\%) }\end{array}$ & Wings (\%) \\
\hline $\mathrm{A}^{1}$ & 83.54 & 27.89 & 28.44 & 9.53 \\
$\mathrm{~B}^{2}$ & 82.90 & 27.46 & 28.62 & 9.40 \\
$\mathrm{C}^{3}$ & 83.63 & 28.30 & 27.60 & 9.32 \\
CV\%** $^{\text {CV }}$ & 1.35 & 4.38 & 4.16 & 4.23 \\
P-value* & 0.48 & 0.51 & 0.30 & 0.68 \\
\hline
\end{tabular}

**Coefficient of variation; *Significant at $\mathrm{P}<0.05$. ${ }^{1} \mathrm{~A}$ (control) $=$ Sorghum and soybean meal + soybean oil; ${ }^{2} \mathrm{~B}=$ Sorghum and soybean meal + corn oil; and ${ }^{3} \mathrm{C}=$ Sorghum and soybean meal + millet and soybean oil.

sorghum-based diets did not affect the carcass yields of broilers (ROCHA et al., 2008). ANDREOTTI et al. (2004) made the same observation in a diet with up to $7.86 \%$ soybean oil at 21 to 42 days.

At 42 days of age, the broilers fed with diets formulated with both corn oil and millet + soybean oil had relative gizzard, heart and liver weights similar to those fed with the control diet ( $\mathrm{P}>0.05$; Table 4). HIDALGO et al. (2004) evaluated 1- to 15-day-old birds and observed increased gizzard weights with millet added at $10 \%$ or more to the feed; however, the authors stated that this increase was related more to the grain size than the ingredient itself. LARA et al. (2006) used corn oil and concluded that different sources of fat did not affect carcass yields, edible offal or certain prime cuts (breasts and thighs).

\section{CONCLUSION}

Millet and corn oil were added to sorghum-based diets without compromising the productivity of broiler chickens. This finding increases options for using different ingredients in the formulation of poultry diets.

Table 4 - Relative weights of edible offal (gizzard, heart and liver) of the broilers at 42 days of age fed with different diets in Uberlandia, Minas Gerais, 2013.

\begin{tabular}{lccc}
\hline Diets & Gizzard (\%) & Heart (\%) & Liver (\%) \\
\hline $\mathrm{A}^{1}$ & 1.66 & 0.51 & 1.67 \\
$\mathrm{~B}^{2}$ & 1.75 & 0.51 & 1.80 \\
$\mathrm{C}^{3}$ & 1.79 & 0.49 & 1.87 \\
$\mathrm{CV}^{* * *}$ & 8.78 & 10.05 & 8.12 \\
P-value* & 0.35 & 0.82 & 0.07 \\
\hline
\end{tabular}

**Coefficient of variation; *Significant at $\mathrm{P}<0.05$. ${ }^{1} \mathrm{~A}$ (control) $=$ Sorghum and soybean meal + soybean oil; ${ }^{2} \mathrm{~B}=$ Sorghum and soybean meal + corn oil; and ${ }^{3} \mathrm{C}=$ Sorghum and soybean meal + millet and soybean oil. 


\section{BIOETHICS AND BIOSSECURITY COMMITTEE APPROVAL}

The Ethics Committee on the Use of Animals at the Universidade Federal de Uberlândia approved this study. All of the procedures were performed in accordance with Registration Protocol CEUA/UFU 116/13.

\section{REFERENCES}

ALMEIDA, A.P.S. et al. Effect of linseed oil and vitamin E consumption on poultry performance and carcass traits. Arquivo Brasileiro de Medicina Veterinária e Zootecnia, v.61, n.3, p.698705, 2009. Available from: <http://www.scielo.br/pdf/abmvz/ v61n3/25.pdf>. Accessed: Dec. 01, 2013. doi: 10.1590/S010209352009000300025 .

ANDREOTTI, M.O. et al. Intestinal transit time, performance, carcass characteristics and body composition in broilers fed isoenergy diets formulated with different levels of soybean oil. Revista Brasileira de Zootecnia, v.33, n.4, p.870-879, 2004. Available from: <http://www.scielo.br/pdf/rbz/v33n4/22083. pdf $>$. Accessed: Nov. 21, 2013. doi: 10.1590/S151635982004000400007 .

BAIÃO, N.C.; LARA, L.J.C. Oil and fat in broiler nutrition. Brazilian Journal of Poultry Science, v.7, n.3, p.129-141, 2005. Available from: <http://www.scielo.br/pdf/rbca/v7n3/ a01v7n3.pdf>. Accessed: Nov. 11, 2013. doi: 10.1590/S1516$635 \times 2005000300001$.

BAURHOO, N. et al. Comparison of corn-based and Canadian pearl-millet-based diets on performance, digestibility, villus morphology, and digestive microbial populations in broiler chickens. Poultry Science, v.90, n.3, p.579-586, 2011. Available from: $<$ http:// ps.oxfordjournals.org/content/90/3/579.full.pdf + html $>$. Accessed: Oct. 30, 2013. doi: 10.3382/ps.2010-00954.

BRASIL (Ministério da Agricultura, Pecuária e Abastecimento). Portaria n.210 de 10 nov. de 1998. Aprova o regulamento técnico da inspeção tecnológica e higiênico-sanitária de carne de aves. Diário Oficial da União, Brasília, DF, 26 nov. 1998. Seção 1. p.226.

COSTA, F.G.P. et al. Performance and eggs quality in laying hens fed diets with soybean and canola oils. Revista Brasileira de Zootecnia, v.37, n.8, p.1412-1418, 2008. Available from: <http:// www.scielo.br/pdf/rbz/v37n8/v37n8a11.pdf $>$. Accessed: Dec. 2, 2013. doi: 10.1590/S1516-35982008000800011.

DAVIS, A.J. et al. Pearl millet as an alternative feed ingredient in broiler diets. Journal of Applied Poultry Research, v.12, n.2, p.137-144, 2003. Available from: <http://japr.oxfordjournals.org/ content/12/2/137.full.pdf + html $>$. Accessed: Nov. 7, 2013. doi: 10.1093/japr/12.2.137.

FURLAN, R.L. Influência da temperatura na produção de frangos de corte. In: SIMPÓSIO BRASIL SUL DE AVICULTURA, 7., 2006, Chapecó, SC. Anais... Concórdia: Embrapa Suínos e Aves, 2006. p.104-135.

GOMES, P.C. et al. Determination of chemical composition and energy value of millet and their use in rations of broilers from 1 to 21 days of age. Revista Brasileira de Zootecnia, v.37, n.9, p.1617-1621, 2008. Available from: <http://www.scielo.br/ pdf/rbz/v37n9/a13v37n9.pdf>. Accessed: Nov. 13, 2013. doi: 10.1590/S1516-35982008000900013.

HARMS, R.H. et al. The effect of corn oil reduction in the diet on laying hen performance. Brazilian Journal of Poultry Science, v.6, n.3, p.183-186, 2004. Available from: <http://www.scielo. br/pdf/rbca/v6n3/a09v6n3.pdf>. Accessed: Nov. 12, 2013 . doi: 10.1590/S1516-635X2004000300009.

HIDALGO, M.A. et al. Use of whole pearl millet in broiler diets. Journal of Applied Poultry Research, v.13, n.2, p.229234, 2004. Available from: <http://japr.oxfordjournals.org/ content/13/2/229.full.pdf + html $>$. Accessed: Oct. 23, 2013. doi: 10.1093/japr/13.2.229

LARA, L.J.C. et al. Carcass yield, composition and fat acid percentage of carcass for broiler fed on different lipid source diets. Arquivo Brasileiro de Medicina Veterinária e Zootecnia, v.58, n.1, p.108-115, 2006. Available from: <http:/www.scielo.br/pdf/ abmvz/v58n1/28787.pdf $>$. Accessed: Nov. 2, 2013. doi: 10.1590/ S0102-09352006000100016.

LEITE, P.R.S.C. et al. Broiler performance and digestibility of sorghum or millet diets with enzymatic complexes. Pesquisa Agropecuária Brasileira, v.46, n.3, p.280-286, 2011. Available from: <http://www.scielo.br/pdf/pab/v46n3/ a08v46n3.pdf $>$. Accessed: Nov. 16, 2013. doi: 10.1590/S0100204X2011000300008.

LEITE, P.R.S.C. et al. Intestinal microflora and broiler performance fed with sorghum or pearl millet with enzymatic complexes. Arquivo Brasileiro de Medicina Veterinária e Zootecnia, v.64, n.6, p.1673-1681, 2012. Available from: $<$ http://www.scielo.br/ pdf/abmvz/v64n6/37.pdf $>$. Accessed: Oct. 22, 2013. doi: 10.1590/ S0102-09352012000600037

MAIORKA, A. et al. Energy and oil levels in broiler starter diets. Ciência Rural, v.38, n.4, p.1099-1104, 2008. Available from: $<$ http://www.scielo.br/pdf/cr/v38n4/a30v38n4.pdf $>$. Accessed: Nov. 19, 2013. doi: 10.1590/S0103-84782008000400030.

MURAKAMI, A.E. et al. Avaliação econômica e desempenho de frangos de corte alimentados com diferentes níveis de milheto em substituição ao milho. Acta Scientiarum. Animal Sciences, v.31, n.1, p.31-37, 2009. Available from: <http://periodicos.uem.br/ojs/ index.php/ActaSciAnimSci/article/view/5761/5761>. Accessed: Nov. 10, 2013. doi: 10.4025/actascianimsci.v31i1.5761.

NASCIF, C.C.C. et al. Determination of energy values of some oils and fats for broilers chickens males and females in the 21 day old. Revista Brasileira de Zootecnia, v.33, n.2, p.375-385, 2004. Available from: <http://www.scielo.br/pdf/rbz/v33n2/21250.pdf $>$. Accessed: Dec. 6, 2013. doi: 10.1590/S1516-35982004000200014.

ROCHA, V.R.R.A. et al. Total replacement of corn by sorghum and slaughterhouse poultry oil in broiler diets. Revista Brasileira de Zootecnia, v.37, n.1, p.95-102, 2008. Available from: <http:// www.scielo.br/pdf/rbz/v37n1/v37n1a14.pdf $>$. Accessed: Nov. 5, 2013. doi: $10.1590 / \mathrm{S} 1516-35982008000100014$

ROSTAGNO, H.S. et al. Tabelas brasileiras para aves e suínos: composição de alimentos e exigências nutricionais. Viçosa: UFVDZO, 2011. 252p.

UBABEF (UNIÃO BRASILEIRA DE AVICULTURA). Relatório anual. São Paulo: UBABEF, 2013. 109p.

Ciência Rural, v.45, n.12, dez, 2015. 